\title{
Drying kinetics of crushed mass of 'jambu': Effective diffusivity and activation energy
}

\author{
Francileni P. Gomes ${ }^{1}$, Osvaldo Resende ${ }^{2}$, Elisabete P. Sousa ${ }^{1}$, \\ Daneil E. C. de Oliveira ${ }^{3} \&$ Francisco R. de Araújo Neto ${ }^{2}$
}

${ }^{1}$ Instituto Federal do Amapá/Departamento de Alimentos, Tecnologia em Alimentos. Macapá, AP. E-mail: fpgleni@yahoo.com.br (Corresponding author) - ORCID: 0000-0003-3107-5374; elisabete_pianco@yahoo.com.br - ORCID: 0000-0003-2055-6674

${ }^{2}$ Instituto Federal Goiano/Campus Rio Verde/Diretoria de Pesquisa e Pós-Graduação. Rio Verde, GO. E-mail: osvaldo.resende@ifgoiano.edu.br - ORCID: 0000-0001-5089-7846; francisco.neto@ifgoiano.edu.br - ORCID: 0000-0003-1064-5614

${ }^{3}$ Instituto Federal de Educação, Ciência e Tecnologia Goiano/Campus Iporá. Iporá, GO. E-mail: oliveira.d.e.c@gmail.com - ORCID: 0000-0002-3824-994X

Key words:

vegetable

convective drying

Acmella oleracea

\begin{abstract}
A B S T R A C T
The aim of this paper was to analyze the drying kinetics, test the Akaike information criterion (AIC) and Schwarz's Bayesian information criterion (BIC) in the selection of models, determine the effective diffusivity and activation energy of the crushed mass of 'jambu' leaves for different conditions of temperature and layer thicknesses. The experiment was carried out at the Food Laboratory of the Brazilian Agricultural Research Corporation (Embrapa) in Macapá-AP. Drying was carried out in air circulation oven with speed of $1.0 \mathrm{~m} \mathrm{~s}^{-1}$ at various temperatures $\left(60,70\right.$ and $\left.80^{\circ} \mathrm{C}\right)$ and layer thicknesses $(0.005$ and $0.010 \mathrm{~m}$ ). The experimental data were fitted to 11 mathematical models. Coefficient of determination $\left(\mathrm{R}^{2}\right)$, mean relative error $(\mathrm{P})$, mean estimated error $(\mathrm{SE})$, Chi-square test $\left(\chi^{2}\right)$, AIC and BIC were the selection criteria for the models. For the effective diffusivity, the Fick's diffusion model was used considering the flat plate geometry. It was found that Midilli and Logarithmic models showed the best fit to the experimental data of drying kinetics. Effective diffusion coefficient increases with increment in the thickness of the material and with the temperature elevation. Activation energy of the material was of $16.61 \mathrm{~kJ} \mathrm{~mol}^{-1}$ for the thickness of $0.005 \mathrm{~m}$, and $16.97 \mathrm{~kJ} \mathrm{~mol}^{-1}$ for the thickness of $0.010 \mathrm{~m}$. AIC and BIC can be additionally included to select models of drying.
\end{abstract}

\section{Palavras-chave:}

hortaliça

secagem convectiva

Acmella oleracea

\section{Cinética de secagem da massa triturada de jambu: Difusividade efetiva e energia de ativação}

\section{R E S U M O}

Objetivou-se com o presente trabalho analisar a cinética de secagem, testar os critérios da informação de Akaike (AIC) e informação Bayesiano de Schwarz (BIC) para seleção dos modelos, determinar a difusividade efetiva e a energia de ativação de massa triturada de folhas de jambu para diferentes condições de temperatura e espessuras de camada. O experimento foi desenvolvido no Laboratório de Alimentos da Empresa Brasileira de Pesquisa Agropecuária (Embrapa), em Macapá - AP. A secagem foi realizada em estufa de circulação de ar com velocidade de $1,0 \mathrm{~m} \mathrm{~s}^{-1}$ em diferentes temperaturas $\left(60,70\right.$ e $\left.80^{\circ} \mathrm{C}\right)$ e espessuras da camada $(0,005$ e $0,010 \mathrm{~m})$. Aos dados experimentais foram ajustados onze modelos matemáticos. $\mathrm{O}$ coeficiente de determinação $\left(\mathrm{R}^{2}\right)$, erro médio relativo $(\mathrm{P})$, erro médio estimado $(\mathrm{SE})$, teste de Qui-quadrado $\left(\chi^{2}\right)$, AIC e BIC, foram os critérios de seleção dos modelos. Para a difusividade efetiva utilizou-se o modelo difusivo de Fick para a forma geométrica de placa plana. Constatou-se que os modelos de Midilli e Logaritmo melhor se ajustam aos dados experimentais da cinética de secagem. $\mathrm{O}$ coeficiente de difusão efetivo aumentou com o incremento da espessura da camada de material e com a elevação da temperatura. A energia de ativação do material foi de $16,61 \mathrm{~kJ} \mathrm{~mol}^{-1}$ para a espessura de $0,005 \mathrm{~m} \mathrm{e}^{\mathrm{de}} 16,97 \mathrm{~kJ} \mathrm{~mol}^{-1}$ para a espessura de $0,010 \mathrm{~m}$. Os critérios de AIC e BIC podem ser incluídos adicionalmente para seleção de modelos de secagem. 


\section{INTRODUCTION}

'Jambu' (Acmella oleracea) is an annual ground herb, with cylindrical stem and height between 0.2 and $0.3 \mathrm{~m}$. It is popularly known as 'jambu', 'agrião bravo' or 'agrião do Pará', and its leaves and flowers cause a slight tingling and numbing sensation on the tongue (Nascimento et al., 2013; Aguiar et al., 2014).

This vegetable is mainly cultivated and consumed in the Northern region of Brazil, being widely used as seasoning in local foods. 'Jambu' has high water content and is perishable. Thus, it requires the application of postharvest technologies to preserve its quality for long periods, allowing for transport and commercialization in markets of other regions (Nascimento et al., 2013; Barbosa et al., 2016).

One technological alternative for preservation is drying, which partially removes the water, causing a reduction in water activity, microbial growth and in enzymatic, physical and chemical reactions (Corrêa et al., 2007). The drying process of a certain product can be described by mathematical models, which represent experimental data of water loss by the material and provide important information for equipment designing, dimensioning, optimization and determination of commercial application feasibility (Costa et al., 2015).

To fit mathematical models to the drying data of plant products, various criteria can be used, such as the magnitudes of coefficient of determination, mean relative error and mean estimated error, chi-square test and residual distribution. Nonetheless, some of these parameters have limitations, thus requiring the adoption of additional criteria in the selection of models to reinforce and endorse decision-taking. In this context, the Akaike Information Criterion (AIC) and Bayesian Information Criterion (BIC) consist in evaluating the models according to the principle of parsimony, since the number of parameters in the models varies.

This study aimed to evaluate the drying kinetics, test AIC and BIC model selection criteria, and determine effective diffusivity and activation energy of crushed mass of 'jambu' leaves for different conditions of temperature and thickness.

\section{Material ANd Methods}

'Jambu' plants were purchased in the municipality of Macapá, AP, Brazil. The species was botanically identified as Acmella oleracea by the Scientific and Technological Research Institute of Amapá, and the exsiccate was deposited at the HAMAB collection as Acmella oleracea F. P. Gomes 01.

The experiment was carried out in February 2017 at the Food Laboratory of the Brazilian Agricultural Research Corporation - Embrapa (Macapá, AP) $\left(0^{\circ} 00^{\prime} 44^{\prime \prime} \mathrm{S} ; 51^{\circ} 04^{\prime}\right.$ 46 ” W; 460 m).

'Jambu' leaves $(20 \mathrm{~kg}$ ) were ground (without addition of water) in a food mixer to obtain a solid homogeneous mass formed by pieces of leaves. Drying was performed in a forcedair oven at temperatures of 60,70 and $80{ }^{\circ} \mathrm{C}$, at relative air humidity $13.09,8.14$ and $5.45 \%$, respectively, estimated by monitoring the relative humidity of the environment using a thermohygrometer, and with layer thicknesses of 0.005 and
$0.010 \mathrm{~m}$, measured with a caliper. Air speed of $1.0 \mathrm{~m} \mathrm{~s}^{-1}$ was measured with an anemometer. The mass of the material was uniformly spread on rectangular stainless-steel trays $(0.278 \mathrm{x}$ $0.178 \mathrm{~m}$ ) in thin layer.

Mathematical models were fit to the drying kinetics experimental data (Eqs. 1 to 11), according to a nonlinear regression analysis by the Gauss-Newton method.

- Page (Page, 1949)

$$
\mathrm{RX}=\exp \left(-\mathrm{k} \mathrm{t} \mathrm{t}^{\mathrm{n}}\right)
$$

- Midilli (Midilli et al., 2002)

$$
\mathrm{RX}=\mathrm{a} \exp \left(-\mathrm{k} \mathrm{t}^{\mathrm{n}}\right)+\mathrm{bt}
$$

- Henderson \& Pabis (Henderson \& Pabis, 1961)

$$
\mathrm{RX}=\mathrm{a} \exp (-\mathrm{kt})
$$

- Approximation of Diffusion (Sharaf-Elden et al., 1980)

$$
\mathrm{RX}=\mathrm{a} \exp (-\mathrm{kt})+(1-\mathrm{a}) \exp (-\mathrm{k} \mathrm{bt})
$$

- Two Terms (Henderson, 1974)

$$
\mathrm{RX}=\mathrm{a} \exp \left(-\mathrm{k}_{\mathrm{o}} \mathrm{t}\right)+\mathrm{b} \exp \left(-\mathrm{k}_{1} \mathrm{t}\right)
$$

- Two-term Exponential (Sharaf-Eldeen et al., 1980)

$$
R X=a \exp (-k t)+(1-a) \exp (-k a t)
$$

- Logarithmic (Yagcioglu et al., 1999)

$$
\mathrm{RX}=\mathrm{a} \exp (-\mathrm{kt})+\mathrm{c}
$$

- Thompson (Thompson et al., 1968)

$$
R X=\exp \left\{\frac{\left[-a-\left(a^{2}+4 b t\right)^{0.5}\right]}{2 b}\right\}
$$

- Newton (Lewis, 1921)

$$
\mathrm{RX}=\exp (-\mathrm{kt})
$$

- Verma (Verma et al., 1985)

$$
\mathrm{RX}=\mathrm{a} \exp (-\mathrm{k} \mathrm{t})+(1-\mathrm{a}) \exp \left(-\mathrm{k}_{1} \mathrm{t}\right)
$$

- Wang \& Singh (Verma et al., 1985)

$$
\mathrm{RX}=1+\mathrm{at}+\mathrm{bt}^{2}
$$

where:

RX - moisture content ratio of the product, dimensionless; 
$\mathrm{k}, \mathrm{k}_{0}, \mathrm{k}_{1}$ - drying constants;

$\mathrm{h}^{-1} ; \mathrm{a}, \mathrm{b}, \mathrm{c}, \mathrm{n}$ - coefficients of the models; and,

$\mathrm{t}$ - drying time, h.

The fit of the models to the experimental data was initially assessed by the standard error of the estimated coefficients and then by the magnitudes of the coefficient of determination $\left(\mathrm{R}^{2}\right)$, mean relative error $(\mathrm{P})$, mean estimated error $(\mathrm{SE})$, and chi-square test $\left(\chi^{2}\right)$ at 0.05 probability level, according to the following equations:

$$
\begin{gathered}
\mathrm{P}=\frac{100}{\mathrm{n}} \sum \frac{|\mathrm{Y}-\hat{\mathrm{Y}}|}{\mathrm{Y}} \\
\mathrm{SE}=\sqrt{\frac{\sum(\mathrm{Y}-\hat{\mathrm{Y}})^{2}}{\mathrm{DF}}} \\
\chi^{2}=\frac{\sum(\mathrm{Y}-\hat{\mathrm{Y}})^{2}}{\mathrm{DF}}
\end{gathered}
$$

where:

$\mathrm{Y}$ - experimental RX value;

$\hat{Y}$ - estimated $R X$ value;

$\mathrm{n}$ - number of observations; and,

DF - degrees of freedom of the model.

In order to select a single model to describe the drying process under each condition, models that obtained the best fits were subjected to Akaike Information Criterion (AIC) and Schwarz's Bayesian Information Criterion (BIC). Lower AIC and BIC values indicate better fit of the model, and BIC is the most rigorous criterion (Wolfinger, 1993).

The information criteria were determined by the following equations:

$$
\begin{gathered}
\mathrm{AIC}=-2 \log \mathrm{L}+2 \mathrm{p} \\
\mathrm{BIC}=-2 \log \mathrm{L}+\mathrm{p} \ln (\mathrm{N}-\mathrm{r})
\end{gathered}
$$

where:

$\mathrm{p}$ - number of parameters of the model;

$\mathrm{N}$ - total number of observations;

$\mathrm{r} \quad$ - rank of the matrix $\mathrm{X}$ (incidence matrix of fixed effects); and,

L - maximum likelihood.

Fick's diffusion model for a flat plate geometry (Brooker et al., 1992), with approximation of eight terms (Afonso Júnior \& Corrêa, 1999), was fitted to the experimental data of drying of 'jambu' leaves crushed mass, according to Eq. 17.

$$
\mathrm{RX}=\frac{8}{\pi^{2}} \sum_{\mathrm{n}=0}^{\infty} \frac{1}{(2 \mathrm{n}+1)^{2}} \exp \left[-\frac{(2 \mathrm{n}+1) \pi^{2} \mathrm{Dt}}{4}\left(\frac{\mathrm{S}}{\mathrm{V}}\right)^{2}\right]
$$

where:

RX - moisture content ratio of the product, dimensionless;
D - effective diffusion coefficient, $\mathrm{m}^{2} \mathrm{~s}^{-1}$;

$\mathrm{S} \quad$ - area of the equivalent plate, $\mathrm{m}^{2}$;

$\mathrm{V} \quad$ - volume of the equivalent plant, $\mathrm{m}^{3}$;

$\mathrm{n}$ - number of terms in the equation; and,

t - time, s.

Arrhenius equation (Eq. 18) was used to correlate the dependence of effective diffusivity on temperature.

$$
\mathrm{D}=\mathrm{D}_{0} \exp \left(\frac{-\mathrm{E}_{\mathrm{a}}}{\mathrm{R} \mathrm{T}_{\mathrm{a}}}\right)
$$

where:

Do - pre-exponential factor, $\mathrm{m}^{2} \mathrm{~s}^{-1}$;

$\mathrm{E}_{\mathrm{a}} \quad$ - activation energy, $\mathrm{J} \mathrm{mol}^{-1}$;

$\mathrm{R}$ - universal gas constant, $8.314 \mathrm{~J} \mathrm{~mol}^{-1} \mathrm{~K}^{-1}$; and,

$\mathrm{T}_{\mathrm{a}}$ - absolute temperature, $\mathrm{K}$.

\section{Results AND Discussion}

Among the models fitted to the experimental data, Approximation of diffusion, Two Terms, Two-Term Exponential, Thompson and Verma reached convergence of fitness in the iterative process. However, they showed high standard error of the estimated coefficients, indicating lack of fit to the experimental data (Table 1). In the present study, standard errors of the estimates higher than 10 times the predicted value were assumed to demonstrate failure in predicting the coefficients. For the other models, the coefficients showed low standard errors of the estimates, indicating convergence of fitness.

The models Midilli, Logarithmic and Wang \& Singh had coefficients of determination $\left(\mathrm{R}^{2}\right)$ higher than $99 \%$, mean estimated error (SE) below 0.0097 and chi-square test $\left(\chi^{2}\right)$ lower than $9.4 \times 10^{-5}$, for the drying conditions (Table 2 ).

Considering the mean relative error $(\mathrm{P})$ lower than or equal to $10 \%$ as an adequate representation of the model (Mohapatra \& Rao, 2005), it can be noted that Midilli, Logarithmic and Wang \& Singh models were the ones that met this criterion and can adequately represent the drying of 'jambu' leaves crushed mass.

Along with the previous statistical parameters (Table 2), Akaike Information Criterion (AIC) and Schwarz's Bayesian Information Criterion (BIC) (Table 3) were also considered as additional parameters to select the best model.

Considering the lowest values of BIC and AIC, the Logarithmic model showed the best fit to the experimental data at temperature of $60^{\circ} \mathrm{C}$ and layer thickness of $0.005 \mathrm{~m}$ and for treatment of $80^{\circ} \mathrm{C}$ and thicknesses of 0.005 and $0.010 \mathrm{~m}$. On the other hand, for the temperature of $60^{\circ} \mathrm{C}$ and thickness of $0.010 \mathrm{~m}$ and temperature of $70{ }^{\circ} \mathrm{C}$ and thicknesses of 0.005 and $0.010 \mathrm{~m}$, the Midilli model fitted best to the data.

Martins et al. (2015), working with 'timbó' (Serjania marginata Casar) leaves, observed that the Logarithmic and Midilli models showed satisfactory fit to the experimental data for the temperatures of 40 and $50^{\circ} \mathrm{C}$, but only Midilli showed good fit for the temperatures of 60 and $70^{\circ} \mathrm{C}$. These authors recommend the Midilli model to predict thin-layer drying of 
Table 1. Standard errors of the estimated coefficients for the models Approximation of diffusion, Two Terms, Two-term Exponential, Thompson and Verma evaluated in the drying kinetics of 'jambu' leaves crushed mass

\begin{tabular}{|c|c|c|c|c|c|c|c|c|c|c|c|}
\hline \multirow{3}{*}{ Model } & \multirow{3}{*}{$\begin{array}{c}\text { Temp. } \\
\left({ }^{\circ} \mathrm{C}\right)\end{array}$} & \multicolumn{5}{|c|}{$0.005 \mathrm{~m}$} & \multicolumn{5}{|c|}{$0.010 \mathrm{~m}$} \\
\hline & & \multicolumn{10}{|c|}{ Coefficients } \\
\hline & & $a$ & b & $\mathbf{k}$ & $\mathbf{n}$ & 9 & a & b & $k$ & $\mathbf{N}$ & 9 \\
\hline \multirow{3}{*}{$\begin{array}{l}\text { Approximation } \\
\text { of diffusion }\end{array}$} & 60 & $1.6 \times 10^{4}$ & $1.8 \times 10^{2}$ & 1.2 & & - & $2.6 \times 10^{4}$ & $2.7 \times 10^{2}$ & 0.9 & & -- \\
\hline & 70 & $3.2 \times 10^{4}$ & $1.1 \times 10^{2}$ & 2.7 & & --- & $3.0 \times 10^{4}$ & $1.2 \times 10^{3}$ & 1.7 & & --- \\
\hline & 80 & $3.4 \times 10^{4}$ & $7.1 \times 10^{4}$ & 0.0 & & --- & $4.2 \times 10^{3}$ & $4.9 \times 10^{3}$ & 0.8 & & --- \\
\hline \multirow{3}{*}{ Two terms } & 60 & $1.3 \times 10^{6}$ & $1.3 \times 10^{6}$ & $1.2 \times 10^{3}$ & & $7.7 \times 10^{2}$ & $1.3 \times 10^{6}$ & $1.3 \times 10^{6}$ & $1.5 \times 10^{2}$ & & $2.5 \mathrm{E}+02$ \\
\hline & 70 & $9.7 \times 10^{5}$ & $9.7 \times 10^{5}$ & $2.3 \times 10^{2}$ & & $6.5 \times 10^{2}$ & $1.9 \times 10^{5}$ & $1.9 \times 10^{5}$ & 5.2 & & 5.4 \\
\hline & 80 & $1.3 \times 10^{6}$ & $1.3 \times 10^{6}$ & $2.3 \times 10^{2}$ & & $2.1 \times 10^{2}$ & $1.9 \times 10^{5}$ & $1.9 \times 10^{5}$ & 7.5 & & 7.3 \\
\hline \multirow{3}{*}{$\begin{array}{l}\text { Two-term } \\
\text { Exponential }\end{array}$} & 60 & $8.4 \times 10^{3}$ & --- & 8.9 & & --- & $1.9 \mathrm{E}+03$ & --- & 2.6 & & --- \\
\hline & 70 & $2.0 \times 10^{3}$ & --- & 5.6 & & --- & $3.1 \times 10^{3}$ & -- & 4.4 & & --- \\
\hline & 80 & $5.1 \times 10^{3}$ & --- & 11.5 & & --- & $6.7 \times 10^{3}$ & --- & 7.4 & & -- \\
\hline \multirow{3}{*}{ Thompson } & 60 & $5.6 \times 10^{5}$ & $2.9 \times 10^{3}$ & --- & & --- & $5.4 \times 10^{5}$ & $2.3 \times 10^{3}$ & -- & & --- \\
\hline & 70 & $3.8 \times 10^{5}$ & $2.9 \times 10^{3}$ & -- & & --- & $6.9 \times 10^{5}$ & $3.3 \times 10^{3}$ & -- & & -- \\
\hline & 80 & $7.6 \times 10^{5}$ & $6.1 \times 10^{3}$ & --- & & --- & $6.6 \mathrm{E}+05$ & $3.7 \times 10^{3}$ & --- & & --- \\
\hline \multirow{3}{*}{ Verma } & 60 & $1.8 \times 10^{4}$ & --- & 1.2 & & 1.2 & $3.0 \times 10^{4}$ & --- & 0.9 & & 1.0 \\
\hline & 70 & $3.2 \times 10^{4}$ & --- & 2.7 & & 2.8 & $4.0 \times 10^{4}$ & -- & 1.8 & & 1.8 \\
\hline & 80 & $2.8 \times 10^{2}$ & --- & 0.1 & & 0.1 & $5.2 \times 10^{2}$ & --- & 0.2 & & 0.2 \\
\hline
\end{tabular}

Table 2. Mean estimated error (SE), mean relative error (P), chi-square test $\left(\chi^{2}\right)$ and coefficient of determination $\left(R^{2}\right)$ for the models evaluated in the drying of 'jambu' leaves crushed mass for different temperatures and thicknesses of 0.005 and $0.010 \mathrm{~m}$

\begin{tabular}{|c|c|c|c|c|c|c|c|c|c|c|c|c|}
\hline \multirow[b]{2}{*}{ Model } & \multicolumn{4}{|c|}{$60^{\circ} \mathrm{C}-0.005 \mathrm{~m}$} & \multicolumn{4}{|c|}{$70^{\circ} \mathrm{C}-0.005 \mathrm{~m}$} & \multicolumn{4}{|c|}{$80^{\circ} \mathrm{C}-0.005 \mathrm{~m}$} \\
\hline & $\begin{array}{c}\text { SE } \\
\text { (decimal) }\end{array}$ & $\begin{array}{c}P \\
(\%)\end{array}$ & $\begin{array}{c}x^{2} \text { (decimal) } \\
\times 10^{-3}\end{array}$ & $\begin{array}{c}\mathrm{R}^{2} \\
(\%)\end{array}$ & $\begin{array}{c}\text { SE } \\
\text { (decimal) }\end{array}$ & $\begin{array}{c}P \\
(\%)\end{array}$ & $\begin{array}{c}\chi^{2} \text { (decimal) } \\
\times 10^{-3}\end{array}$ & $\begin{array}{c}R^{2} \\
(\%)\end{array}$ & $\begin{array}{c}\text { SE } \\
\text { (decimal) }\end{array}$ & $\begin{array}{c}P \\
(\%)\end{array}$ & $\begin{array}{c}x^{2} \text { (decimal) } \\
\times 10^{-3}\end{array}$ & $\begin{array}{c}R^{2} \\
(\%)\end{array}$ \\
\hline Wang \& Singh & 0.007 & 4.2 & 0.05 & 99.94 & 0.011 & 6.2 & 0.13 & 99.87 & 0.011 & 2.3 & 0.13 & 99.84 \\
\hline Page & 0.030 & 18.5 & 0.90 & 99.06 & 0.025 & 22.1 & 0.62 & 99.38 & 0.026 & 6.9 & 0.65 & 99.22 \\
\hline Newton & 0.063 & 41.1 & 3.94 & 95.72 & 0.058 & 51.2 & 3.35 & 96.50 & 0.065 & 18.8 & 4.21 & 94.71 \\
\hline Midilli & 0.007 & 3.5 & 0.05 & 99.96 & 0.008 & 4.1 & 0.07 & 99.94 & 0.008 & 1.5 & 0.06 & 99.93 \\
\hline Logarithmic & 0.007 & 3.8 & 0.05 & 99.96 & 0.009 & 5.8 & 0.08 & 99.92 & 0.008 & 1.7 & 0.06 & 99.93 \\
\hline \multirow[t]{3}{*}{ Henderson \& Pabis } & 0.056 & 36.4 & 3.17 & 96.70 & 0.050 & 44.5 & 2.49 & 97.52 & 0.055 & 15.4 & 3.04 & 96.36 \\
\hline & \multicolumn{4}{|c|}{$60^{\circ} \mathrm{C}-0.010 \mathrm{~m}$} & \multicolumn{4}{|c|}{$70^{\circ} \mathrm{C}-0.010 \mathrm{~m}$} & \multicolumn{4}{|c|}{$80^{\circ} \mathrm{C}-0.010 \mathrm{~m}$} \\
\hline & $\begin{array}{c}\text { SE } \\
\text { (decimal) }\end{array}$ & $\begin{array}{c}P \\
(\%)\end{array}$ & $\begin{array}{c}x^{2} \text { (decimal) } \\
\times 10^{-3}\end{array}$ & $\begin{array}{c}R^{2} \\
(\%)\end{array}$ & $\begin{array}{c}\text { SE } \\
\text { (decimal) }\end{array}$ & $\begin{array}{c}P \\
(\%)\end{array}$ & $\begin{array}{c}\chi^{2} \text { (decimal) } \\
\times 10^{-3}\end{array}$ & $\begin{array}{l}R^{2} \\
(\%)\end{array}$ & $\begin{array}{c}\text { SE } \\
\text { (decimal) }\end{array}$ & $\begin{array}{c}P \\
(\%)\end{array}$ & $\begin{array}{c}x^{2} \text { (decimal) } \\
\times 10^{-3}\end{array}$ & $\begin{array}{l}\mathrm{R}^{2} \\
(\%)\end{array}$ \\
\hline Wang \& Singh & 0.009 & 7.3 & 0.09 & 99.91 & 0.013 & 4.2 & 0.18 & 99.81 & 0.008 & 1.8 & 0.06 & 99.93 \\
\hline Page & 0.028 & 24.1 & 0.78 & 99.16 & 0.023 & 8.6 & 0.54 & 99.45 & 0.026 & 8.1 & 0.70 & 99.19 \\
\hline Newton & 0.061 & 52.2 & 3.71 & 95.88 & 0.067 & 26.7 & 4.52 & 95.19 & 0.061 & 20.4 & 3.78 & 95.42 \\
\hline Midilli & 0.007 & 5.1 & 0.05 & 99.95 & 0.007 & 1.6 & 0.05 & 99.95 & 0.006 & 1.3 & 0.04 & 99.96 \\
\hline Logarithmic & 0.007 & 6.2 & 0.05 & 99.94 & 0.010 & 3.1 & 0.10 & 99.90 & 0.006 & 1.3 & 0.04 & 99.96 \\
\hline Henderson \& Pabis & 0.054 & 46.5 & 2.91 & 96.89 & 0.058 & 22.6 & 3.35 & 96.58 & 0.054 & 17.5 & 2.89 & 96.65 \\
\hline
\end{tabular}

Table 3. Schwarz's Bayesian Information Criterion (BIC) and Akaike Information Criterion (AIC) for the models that fitted best to the drying data of the 'jambu' leaves crushed mass under different conditions of temperature and layer thickness

\begin{tabular}{|c|c|c|c|c|c|c|}
\hline \multirow{2}{*}{$\begin{array}{c}\text { Model/ } \\
\text { Treatments }\end{array}$} & \multicolumn{2}{|c|}{ Wang \& Singh } & \multicolumn{2}{|c|}{ Midilli } & \multicolumn{2}{|c|}{ Logarithmic } \\
\hline & BIC & AIC & BIC & AIC & BIC & AIC \\
\hline $60^{\circ} \mathrm{C}-0.005 \mathrm{~m}$ & -166.91 & -170.57 & -166.66 & -172.75 & -169.44 & -174.32 \\
\hline $60{ }^{\circ} \mathrm{C}-0.010 \mathrm{~m}$ & -159.29 & -163.39 & -182.00 & 188.84 & -167.35 & -172.81 \\
\hline $70^{\circ} \mathrm{C}-0.005 \mathrm{~m}$ & -133.46 & -136.87 & -144.68 & -150.35 & -141.36 & -145.90 \\
\hline $70^{\circ} \mathrm{C}-0.010 \mathrm{~m}$ & -148.28 & -152.17 & -177.95 & -184.43 & -161.70 & -166.88 \\
\hline $80^{\circ} \mathrm{C}-0.005 \mathrm{~m}$ & -121.09 & -124.22 & -132.93 & -138.16 & -134.09 & -138.26 \\
\hline $80^{\circ} \mathrm{C}-0.010 \mathrm{~m}$ & -162.98 & -166.63 & -172.85 & -178.94 & -175.79 & -180.67 \\
\hline
\end{tabular}

'timbó' leaves, because of its good fit to all drying conditions studied. The same behavior was found by Goneli et al. (2014a) in the drying of aroeira leaves at temperatures of 40, 50, 60 and $70^{\circ} \mathrm{C}$, and by Martinazzo et al. (2007) in the drying of lemongrass leaves at temperatures of $30,40,50$ and $60{ }^{\circ} \mathrm{C}$.

According to Goneli et al. (2014b), the best fit of the Midilli model to the experimental data of drying of medicinal plants is probably associated with the fast loss of water in the initial stages of the process in these materials, generating a drying curve that is sharper and best characterized mathematically by this model.
Only the parameter $\mathrm{k}$ tended to vary its magnitude with the variation in the drying layer thickness (Table 4). As drying air temperature increased, no trend was observed. Goneli et al. (2014a), studying the drying kinetics of 'erva baleeira' (Cordia verbenacea $\mathrm{DC}$.) leaves, observed no trend in the parameters (a) and (n) for the Midilli model. Sousa et al. (2017) did not find a defined trend for the constant (n) of the Midilli model with the increment in temperature and thickness, observing values from 0.949 to 1.148 in the pequi pulp drying. The values found in the present study are within the range described by Sousa et al. (2017). 
Table 4. Coefficients of the models that fitted best to the drying data of 'jambu' leaves crushed mass under different conditions of temperature and thickness

\begin{tabular}{|c|c|c|c|c|c|c|c|c|c|}
\hline \multirow{3}{*}{ Model } & \multirow{3}{*}{$\begin{array}{c}\text { Temperature } \\
\left({ }^{\circ} \mathrm{C}\right)\end{array}$} & \multicolumn{4}{|c|}{$0.005 \mathrm{~m}$} & \multicolumn{4}{|c|}{$0.010 \mathrm{~m}$} \\
\hline & & \multicolumn{8}{|c|}{ Coefficients } \\
\hline & & $a$ & b & k & $\mathrm{n}$ & $a$ & b & $k$ & $\mathrm{n}$ \\
\hline \multirow{3}{*}{ Midilli } & 60 & 1.003416 & -0.044528 & 0.073914 & 1.061702 & 1.004232 & -0.025116 & 0.043710 & 1.115153 \\
\hline & 70 & 1.005617 & -0.032338 & 0.139091 & 1.123543 & 1.001743 & -0.024922 & 0.051771 & 1.249553 \\
\hline & 80 & 1.010381 & -0.090987 & 0.075519 & 1.129995 & 1.007867 & -0.055776 & 0.048866 & 1.048359 \\
\hline \multirow{3}{*}{ Logarithmic } & 60 & 3.286140 & -2.279470 & 0.037430 & - & 3.378600 & -2.368020 & 0.022860 & - \\
\hline & 70 & 1.951988 & -0.936192 & 0.095699 & - & 4.302200 & -3.286370 & 0.022420 & - \\
\hline & 80 & 12.695900 & -11.680600 & 0.013600 & - & 6.177150 & -5.167520 & 0.017370 & - \\
\hline
\end{tabular}

The drying constant $\mathrm{k}$ of the Midilli and Logarithmic models tended to decrease with the increment in layer thickness for the same temperature, except at $80{ }^{\circ} \mathrm{C}$ for the Midilli model. According to Sousa et al. (2017), increments of thickness reduce the drying rate and also the constant $k$.

The curves fitted by the Logarithmic model and behavior of the effective diffusion coefficients for the drying kinetics of 'jambu' leaves crushed mass are shown in Figure 1.

Increments in drying air temperature directly reduce the time required to dry the product (Figure 1A). This phenomenon has also been observed by different researchers

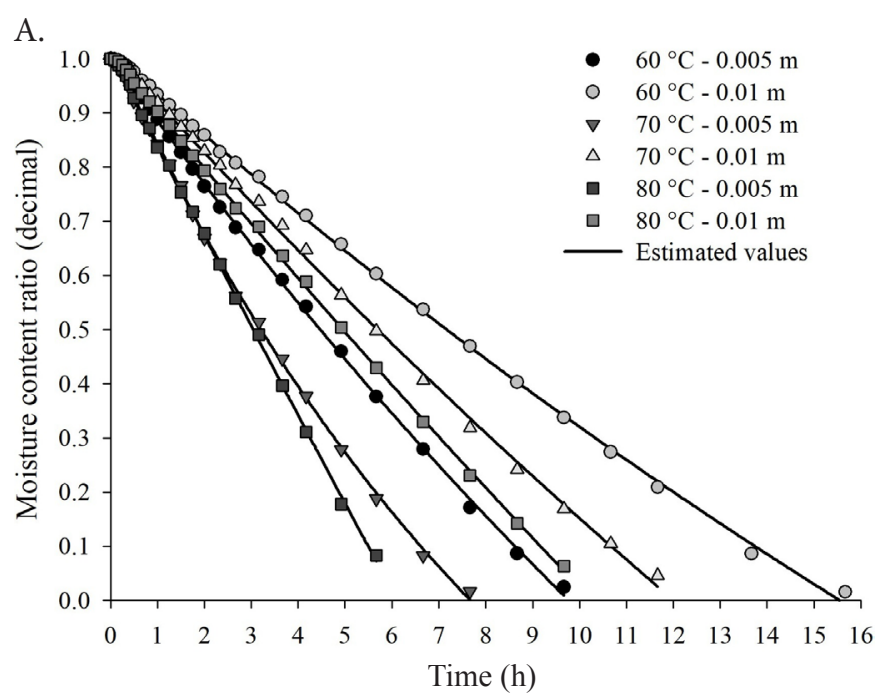

B.

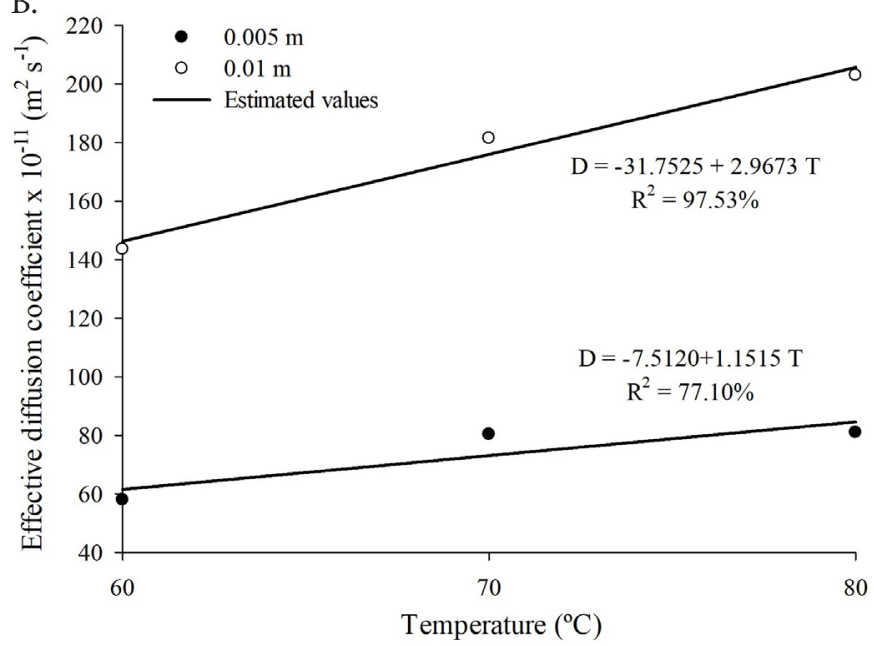

Figure 1. Drying kinetics data obtained experimentally and estimated by the Logarithmic model (A) and mean value of effective diffusion coefficient - D (B), obtained in the drying of 'jambu' leaves crushed mass for thicknesses of 0.005 and $0.010 \mathrm{~m}$ and temperatures of 60,70 and $80{ }^{\circ} \mathrm{C}$ in various agricultural products (Martinazzo et al., 2007; Goneli et al., 2014a, b; Nascimento et al., 2015; Smaniotto et al., 2017). The drying of 'jambu' leaves crushed mass was influenced by layer thickness along the drying time, and the values increased over time as thickness increased. Similar behavior was observed by Sousa et al. (2017) studying pequi pulp drying kinetics in convective drying under different conditions of temperature $\left(50,60,70\right.$ and $\left.80^{\circ} \mathrm{C}\right)$ and thickness (0.005; 0.010 and $0.015 \mathrm{~m})$.

As demonstrated in Figure 1B, the effective diffusion coefficient tended to increase with the elevation of drying air temperature. In addition, the $0.010 \mathrm{~m}$ thickness of the material led to higher effective diffusion coefficients in comparison to $0.005 \mathrm{~m}$ for the three temperatures studied. This fact may have occurred because of the water mass flow generated when a homogeneous mass of material is subjected to drying. Sousa et al. (2017) observed an increasing trend in effective diffusivity with the increment in pequi pulp layer thickness and with the elevation of temperature. Diffusivity represents the speed with which the water moves from the inside to the surface of the material, thus being vaporized (Menezes et al., 2013). Therefore, the higher the temperature, the faster the water movement from the food to the environment.

Effective diffusion coefficients between $0.66 \times 10^{-11}$ and $12.07 \times 10^{-11} \mathrm{~m}^{2} \mathrm{~s}^{-1}$ were reported by Martins et al. (2015) for the drying of 'timbó' leaves within the temperature range from 40 to $70^{\circ} \mathrm{C}$, respectively. Lower values were obtained for the effective diffusion coefficients of 'jambu' leaves crushed mass, which ranged between $5.79 \times 10^{-10}$ and $2.03 \times 10^{-9} \mathrm{~m}^{2} \mathrm{~s}^{-1}$ for the thicknesses of 0.005 and $0.010 \mathrm{~m}$, respectively. These values reinforce the higher speed of exit of water from the product when the material is homogeneous.

The activation energy $\left(E_{a}\right)$ for the drying of 'jambu' leaves crushed mass was equal to $16.61 \mathrm{~kJ} \mathrm{~mol}^{-1}$ for the thickness of $0.005 \mathrm{~m}$ and to $16.97 \mathrm{~kJ} \mathrm{~mol}^{-1}$ for the thickness of $0.010 \mathrm{~m}$. Goneli et al. (2014a), studying the drying of 'erva baleeira' leaves, reported activation energy of $62.89 \mathrm{~kJ} \mathrm{~mol}^{-1}$. Rocha et al. (2012) found $\mathrm{E}_{\mathrm{a}}$ of $77.16 \mathrm{~kJ} \mathrm{~mol}^{-1}$ in the drying of thyme, whereas Goneli et al. (2014b) reported $74.96 \mathrm{~kJ} \mathrm{~mol}^{-1}$ for the drying of aroeira leaves and Martins et al. (2015) obtained $81.39 \mathrm{~kJ} \mathrm{~mol}^{-1}$ in the drying of 'timbó' leaves. Lower $\mathrm{E}_{\mathrm{a}}$ values in the 'jambu' leaves crushed mass evidenced the need for lower energy to trigger the water diffusion process, in comparison to the leaves of 'erva baleeira', thyme, aroeira and 'timbó'.

It is important to highlight that 'jambu' leaves were crushed before drying, and such alteration in its original structure may have favored the exit of water from the material, resulting in lower activation energy. 
Such different values of activation energy for agricultural products can be attributed to their physical and biological characteristics (Martins et al., 2015). Corrêa et al. (2007) described the activation energy as the difficulty with which water molecules break the energy barrier during the movement inside the product, and the lower the activation energy, the higher the water diffusivity.

\section{Conclusions}

1. Midilli and Logarithmic models showed the best fit to the experimental data of drying of 'jambu' leaves crushed mass.

2. Effective diffusion coefficient tends to increase with the increment in layer thickness and elevation of temperature.

3. The dependence of diffusivity on temperature was described by the Arrhenius equation, with activation energy of $16.611 \mathrm{~kJ} \mathrm{~mol}^{-1}$ for the thickness of $0.005 \mathrm{~m}$ and $16.975 \mathrm{~kJ} \mathrm{~mol}^{-1}$ for the thickness of $0.010 \mathrm{~m}$.

4. The Akaike Information Criterion (AIC) and Schwarz's Bayesian Information Criterion (BIC) can be additionally included to select models of drying.

\section{ACKNOWLedgments}

To the Federal Institute of Education, Science and Technology Goiano for financial support, to the Federal Institute of Amapá for the release to conduct the study and to EMBRAPA/Amapá for providing the facilities. To CAPES, FAPEG, FINEP and CNPq for the financial support.

\section{Literature Cited}

Afonso Júnior, P. C.; Corrêa, P. C. Comparação de modelos matemáticos para descrição da cinética de secagem em camada fina de sementes de feijão. Revista Brasileira de Engenharia Agrícola e Ambiental, v.3, p.349-353, 1999. https://doi. org/10.1590/1807-1929/agriambi.v3n3p349-353

Aguiar, J. P. L.; Yuyama, L. K. O.; Souza, F. das C. do A.; Pessoa, A.; Biodisponibilidade do ferro do jambu (Spilanthes oleracea L.): Estudo em murinos. Revista Pan-Amazônica de Saúde, v.5, p.1924. 2014. https://doi.org/10.5123/S2176-62232014000100002

Barbosa, A. F.; Sabaa-Srur, D. F.; Maia, J. G. S.; Sabaa-Srur, A. U. O. Microbiological and sensory evaluation of jambu (Acmella oleracea L.) dried by cold air circulation. Food Science Technology, v.36, p.24-29, 2016. https://doi.org/10.1590/1678-457X.6827

Brooker, D. B.; Bakker-Arkema, F. W.; Hall, C. W. Drying and storage of grains and oilseeds. Westport: The Avi Publishing Company, 1992. 450p.

Corrêa, P. C.; Resende, O.; Martinazzo, A. P.; Goneli, A. L. D.; Botelho, F. M. Modelagem matemática para a descrição do processo de secagem do feijão (Phaseolus vulgaris L.) em camadas delgadas. Engenharia Agrícola, v.27, p.501-510, 2007. https://doi. org/10.1590/S0100-69162007000300020

Costa, L. M.; Resende, O.; Gonçalves, D. N.; Oliveira, D. E. C. de. Modelagem matemática da secagem de frutos de crambe em camada delgada. Bioscience Journal, v.31, p.392-403, 2015. https:// doi.org/10.14393/BJ-v31n2a2015-22340
Goneli, A. L. D.; Nasu, A. K.; Gancedo, R.; Araújo, W. D.; Sarath, K. L. L. Cinética de secagem de folhas de erva baleeira (Cordia verbenacea DC.). Revista Brasileira de Plantas Medicinais, v.16, p.434-443, 2014a. https://doi.org/10.1590/1983-084X/13_041

Goneli, A. L. D.; Vieira, M. do C.; Vilhasanti, H. da C. B.; Gonçalves, A. A. Modelagem matemática e difusividade efetiva de folhas de aroeira durante a secagem. Pesquisa Agropecuária Tropical, v.44, p.56-64, 2014b. https://doi.org/10.1590/S198340632014000100005

Henderson, S. M. Progress in developing the thin layer drying equation. Transactions of the American Society of Agricultural Engineers, v.17, p.1167-1168. 1974. https://doi.org/10.13031/2013.37052

Henderson, S. M.; Pabis, S. Grain drying theory. II: Temperature effects on drying coefficients. Journal of Agricultural Engineering Research, v.6, p.169-174. 1961.

Lewis, W. K. The rate of drying of solid materials. The Journal of Industrial and Engineering Chemistry, v.13, p.427-432, 1921. https://doi.org/10.1021/ie50137a021

Martinazzo, A. P.; Corrêa, P. C.; Resende, O.; Melo, E. de C. Análise e descrição matemática da cinética de secagem de folhas de capim-limão. Revista Brasileira de Engenharia Agrícola e Ambiental, v.11, p.301-306, 2007. https://doi.org/10.1590/ S1415-43662007000300009

Martins, E. A. S.; Lage, E. Z.; Goneli, A. L. D.; Hartmann Filho, C. P.; Lopes, J. G. Cinética de secagem de folhas de timbó (Serjania marginata Casar). Revista Brasileira de Engenharia Agrícola e Ambiental, v.19, p.238-244, 2015. https://doi.org/10.1590/18071929/agriambi.v19n3p238-244

Menezes, M. L. de; Ströher, A. P.; Pereira, N. C.; Barros, S. T. D. de. Análise da cinética e ajustes de modelos matemáticos aos dados de secagem do bagaço do maracujá-amarelo. Engevista, v.15, p.176-186, 2013.

Midilli, A.; Kucuk, H.; Yapar, Z. A new model for single layer drying. Drying Technology, v.20, p.1503-1513. 2002. https://doi. org/10.1081/DRT-120005864

Mohapatra, D.; Rao, P. S. A thin layer drying model of parboiled wheat. Journal of Food Engineering, v.66, p.513-518, 2005. https://doi. org/10.1016/j.jfoodeng.2004.04.023

Nascimento, A. M.; Souza, L. M. de; Baggio, C. H.; Werner, M. F. de P.; Ferreira, D. M.; Silva, L. M. da; Sassaki, G. L.; Gorin, P. A. J.; Iacomini, M.; Cipriani, T. R. Gastroprotective effect and structure of a rhamnogalacturonan from Acmella oleracea. Phytochemistry, v.85, p.137-142, 2013. https://doi.org/10.1016/j. phytochem.2012.08.024

Nascimento, V. R. G.; Biagi, J. D.; Oliveira, R. A. de. Modelagem matemática da secagem convectiva com radiação infravermelha de grãos de Moringa oleifera. Revista Brasileira de Engenharia Agrícola e Ambiental, v.19, p.686-692, 2015. https://doi. org/10.1590/1807-1929/agriambi.v19n7p686-692

Page, G. E. Factors influencing the maximum rates of air drying shelled corn in thin layers. West Lafayette: Purdue University, 1949. Thesis

Rocha, R. P. da; Melo, E. de C.; Corbín, J. B.; Berbert, P. A.; Donzeles, S. M. L.; Tabar, J. A. Cinética del secado de tomillo. Revista Brasileira de Engenharia Agrícola e Ambiental, v.16, p.675-683, 2012. https://doi.org/10.1590/S1415-43662012000600013

Sharaf-Eldeen, Y. I.; Blaisdell, J. L.; Hamdy, M. Y. A model for ear corn drying. Transactions of the American Society of Agricultural Engineers, v.23, p.1261-1265. 1980. https://doi. org/10.13031/2013.34757 
Smaniotto, T. A. de S.; Resende, O.; Sousa, K. A. de; Oliveira, D. E. C. de; Campos, R. C. Drying kinetics of sunflower grains. Revista Brasileira de Engenharia Agrícola e Ambiental, v.21, p.203-208, 2017. https://doi.org/10.1590/1807-1929/agriambi.v21n3p203-208

Sousa, E. P. de; Figueirêdo, R. M. F. de; Gomes, J. P.; Queiroz, A. J. de M.; Castro, D. S. de; Lemos, D. M. Mathematical modeling of pequi pulp drying and effective diffusivity determination. Revista Brasileira de Engenharia Agrícola e Ambiental, v.21, p.493-498, 2017. http:// dx.doi.org/10.1590/1807-1929/agriambi.v21n7p493-498

Thompson, T. L.; Peart, R. M.; Foster, G. H. Mathematical simulation of corn drying: A new model. Transactions of the American Society of Agricultural Engineers, v.11, p.582-586. 1968. https:// doi.org/10.13031/2013.39473
Verma, L. R.; Bucklin, R. A.; Endan, J. B.; Wratten, F. T. Effects of drying air parameters on rice drying models. Transactions of the American Society of Agricultural Engineers, v.28, p.296-301. 1985. https://doi.org/10.13031/2013.32245

Wolfinger, R. D. Covariance structure selection in general mixed models. Communications in Statistics, v.22, p.1079-1106, 1993. https://doi.org/10.1080/03610919308813143

Yagcioglu, A.; Degirmencioglu, A.; Cagatay, F. Drying characteristics of laurel leaves under different conditions. In: International Congress on Agricultural Mechanization and Energy, 7, 1999, Adana. Proceedings... Adana: Faculty of Agriculture, Cukurova University, 1999. p.565-569. 